\title{
GRACZ W ROLI NARRATORA - NA PRZYKŁADZIE GIER KOMPUTEROWYCH TYPU FPP
}

$\begin{array}{cl}\text { JULIUSZ KONCZALSKI } & \begin{array}{l}\text { Wydział Nauk Humanistycznych Uniwersytet Kardynała Stefana Wyszyńskiego; } \\ \text { Faculty of Humanities Cardinal Stefan Wyszyński University in Warsaw (Poland). } \\ \text { juliusz.konczalski@gmail.com }\end{array}\end{array}$

(...) narracja jest strukturą znaczącą, w jaką my sami w toku naszego życia ujmujemy i odnosimy do siebie zdarzenia i działania, nadając im w ten sposób zrozumiałość. Życie ludzkie nie składa się z niepowiązanych zdarzeń i czynności.

Barbara Hardy ${ }^{1}$

Według Barbary Hardy narracja jest prymarną ludzką strukturą rozumienia². Czy będzie to struktura nabyta, czy nie, jest dla naszych rozważań sprawą drugorzędną. Ważne, że każdy z nas od najmłodszych lat spotyka się z narracją prowadzoną za pośrednictwem różnych mediów i na różne sposoby. Czy będą to bajki czytane nam przez rodziców, czy filmy animowane, czy opowieści rodziców lub dziadków - opowiadanie towarzyszy nam od zawsze, jest swoistą kluczową składową naszej ziemskiej tułaczki. Przygotowywani jesteśmy poniekąd do pisania własnych opowieści, interpretowania wydarzeń naszego własnego życia w kontekście jakiejś szerszej fabuły, którą sami określamy. Wesprzyjmy się teorią Jonathana Cullera ${ }^{3}$. Oto prosta historia chłopca, który zakochuje się w koleżance z klasy, ich początkowa miłość

${ }^{1}$ K. Rosner, Narracja, tożsamość i czas, Kraków 2006, s. 27.

${ }^{2}$ Tamże.

${ }^{3}$ J. Culler, Narracja, [w:] Teoria literatury, thum. M. Bassaj, Warszawa 1998, s. 102. 
natrafia na jakieś przeciwności (sprzeciw rodziców, klasowe przytyki etc.), by w ostatecznym rozrachunku cała opowieść skończyła się tzw. happy endem. Idąc tropem Cullera, historia miłości może być opowiedziana przez każdego z nas zupełnie inaczej, za pomocą zupełnie innych dyskursów. Dla jednego będzie to historia nieszczęśliwego ojca, który przeżywa miłosne rozterki córki, dla dziewczyny opowieść o zmaganiu się z opinią klasowego stada, a dla samego nieszczęśliwie zakochanego chłopca opowieść o drodze ku miłości. Narracja pozwoli nam jednak uporządkować te opowieści, sprawić, że raz za razem ten sam temat ujrzymy w nieco innym ujęciu, z nieco innej perspektywy. Tak właśnie funkcjonuje literatura, a co za tym idzie i film, i stanowiące przedmiot tej pracy - gry wideo ${ }^{4}$. Choć w tak zwanej popkulturze pula tematów wydaje się być skończona (perypetie miłosne i wojenna zawierucha to w zasadzie żelazny kanon), sposób ich ukazania zarówno dla każdej ze wspomnianych dziedzin sztuki, jak i nawet w ich obrębie, może być radykalnie inny.

Jednak narracja nie jest dziś już domeną tylko sztuki. Warto na marginesie spojrzeć na takie narzędzia „,codziennego użytku” jak chociażby media społecznościowe - Facebook czy Twitter. Każde z nich jest tak naprawdę głęboko zapośredniczonym akcesorium, pozwalającym kreować opowieść o samym sobie. Tę historię opowiadamy wszystkim, którzy mają dostęp do

${ }^{4}$ Gra wideo czy gra komputerowa? Mimo pewnych historycznych różnic terminy te dziś mogą być i często są stosowane zamiennie na określenie tych samych rodzajów gier. Jednak ze względów historycznych bywa, że terminem gra wideo określa się gry na konsole (Xbox 360, PlayStation 3, Nintendo Wii, PlayStation Vita, PSP). W Polsce, ze względu na popularność pierwszych komputerów (ZX Spectrum, Atari, Commodore C64), początkowo granie kojarzone bywało głównie z komputerami. Dlatego przystawki do telewizorów, takie jak kopia japońskiego Famicomu (Nintendo Entertaining System) czyli Pegasus, umożliwiały granie w gry wideo (bo konsola była podłączana do TV). Jednak zarówno w konsoli, jak i w tradycyjnie rozumianym komputerze mamy te same podzespoły, a dziś gry wideo ukazują się zarówno na konsole, jak i pecety. 
naszych profili. Kreujemy swoje własne symulakrum ${ }^{5}$, korzystając oczywiście z naszych życiowych faktów, ale za sprawą własnej kreacji opowiadamy coś, co tylko częściowo ma związek z rzeczywistością. Najważniejsze i przesądzające pytanie brzmi zatem: czy w ogóle można dojść do prawdy o nas samych, analizując tylko nasz profil w mediach społecznościowych? Odpowiedź wydaje się jednoznaczna - nie.

W swoim artykule zamierzam przyjrzeć się temu, w jaki sposób gry wideo podchodzą do kwestii narracji. Jak gracz, będący zarówno odbiorcą, jak i samym spiritus movens akcji, wpływa na prowadzenie narracji w grach, jak zmienia się podejście do opowiadania nawet najbardziej - wydawałoby się - „wyświechtanych” fabuł? Chciałbym jednak odnieść się nie tylko do teorii narracji, lecz może przede wszystkim zwrócić uwagę na dwa niemożliwe do zakwestionowania aspekty gier. Aspekt performatywny, a także postmodernistyczne, Baudrillardowskie zapośredniczenie gier wideo, mające kolosalne znaczenie, będące w zasadzie punktem wyjścia do każdej „,growej”6 opowieści.

\section{Narracyjny charakter gier wideo - zwycięstwo nie jest już celem}

Gdyby tak spojrzeć na historię gier wideo od czasów Ralpha Baera po współczesność, można odnieść wrażenie, że od samego początku celem towarzyszącego jej nieustającego rozwoju technologicznego wcale nie było stworzenie coraz to lepszych gier, w których gracze będą szukali zwycięstwa. Wręcz przeciwnie, od samego początku gry dążyły do tego, by oprócz typowo zręcznościowego, zero-jedynkowego

\footnotetext{
${ }^{5}$ Obraz samego siebie - jak chcemy być postrzegani przez innych.

${ }^{6}$ Przymiotnik „growy” nie istnieje, przynajmniej jeszcze nie. Mam tego świadomość, niemniej z racji, że w środowisku samych graczy, a także autorów i badaczy zajmujących się tą problematyką, funkcjonuje on już od kilkunastu lat, nie sposób ignorować jego obecności. Niemniej, by zachować zgodność z językowymi prawami, biorę ów nieistniejący przymiotnik w cudzysłów.
} 
systemu: zwycięzca - przegrany, można było zawrzeć w nich coś jeszcze. Tym czymś była opowieść. $Z$ początku dążenie do odtworzenia czegoś, co znamy, a później dążenie ku idealnemu zapośredniczeniu ${ }^{7}$. Doskonale widać to już w jednej z pierwszych gier - Tennis for Two, zaprojektowanej przez Williama Higinbothama w 1958 roku.

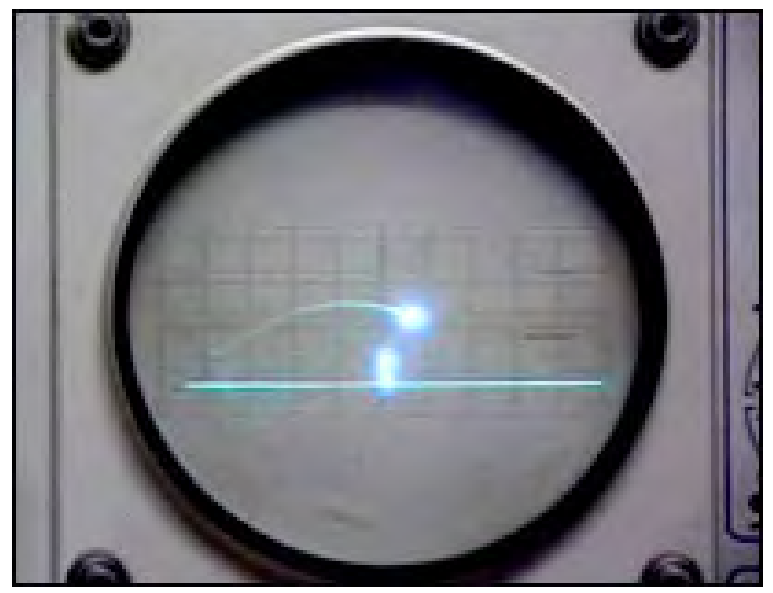

Rysunek 1. Tennis for Two Williama Higinbothama na oscyloskopie

Higinbotham, naukowiec pracujący w Brookhaven National Laboratory (Upton, Nowy Jork), gdzie zajmował się bronią nuklearną ${ }^{8}$, stworzył Tennis for Two w ramach atrakcji na zbliżający się kolejny „dzień otwarty” instytucji, w której pracował. Gra imitująca tenis, choć w niekonwencjonalnym rzucie z boku kortu, nie zliczała punktów grającym. Czy gracze sami je zliczali? Trudno powiedzieć, niemniej jeśli założymy, że koniec każdej opowieści kryje się w jej początku, nie trudno oprzeć się wrażeniu, że ten właśnie brak

${ }^{7}$ Nie chodzi o to, by gry odsyłały nas do rzeczywistości, ale raczej do czegoś, co już znamy i być może, o czym sądzimy, że ową rzeczywistością jest. Wątek ten rozwinę w dalszej części pracy.

${ }^{8}$ B. Kluska, Dawno temu w grach, Łódź 2008. 
zliczania punktów stanie się w gruncie rzeczy najważniejszym lejtmotywem dalszego rozwoju gier wideo, choć do dziś bagatelizowanym i pozostającym w cieniu ich technologicznego rozwoju.

Zatem jeśli zliczanie punktów, a więc ów rywalizacyjny charakter gier, w którym zawsze mamy zwycięzcę i przegranego, nie było najważniejsze, to co? Odpowiedź brzmi jednoznacznie - opowieść. Tennis for Two to prehistoryczna wersja wirtualnego, komputerowego tenisa. Pierwsza gra, która pokazuje, że do gry w tenisa niepotrzebne będą w przyszłości już rakiety, kort i partner stojący po drugiej stronie. Wszystkie te elementy zostaną zastąpione wirtualnymi odpowiednikami. Co ciekawe, twórca gry nadaje jej tytuł Tennis for Two - tenis dla dwojga. Taki zabieg od razu uruchamia ów wspomniany we wstępie proces narracyjny w głowie odbiorcy. Za chwile zobaczę grę $\mathrm{w}$ tenisa, która $\mathrm{z}$ moim dotychczasowym wyobrażeniem ma niewiele wspólnego, jednak w iście Baudrillardowskim stylu nawiązuje do tradycyjnego tenisa nie tylko tytułem. Mamy imitację kortu, mamy piłkę, siatkę, nie widać jedynie zawodników. Jestem przekonany, że nikt z widzów i odwiedzających instytucję, w której pracował Higinbotham, nawet przez chwilę nie pomyślał o zakwestionowaniu zasadności nadania grze takiego tytułu, czy podważeniu tego, że oto na ekranie oscyloskopu widzi „najprawdziwszy" (a jednak jakże inny) mecz tenisowy.

Tennis for Two pokazuje, że już sam tytuł odgrywa w grze bardzo istotną rolę narracyjnego wprowadzenia w opowieść, która będzie następnie przedmiotem samej gry. 


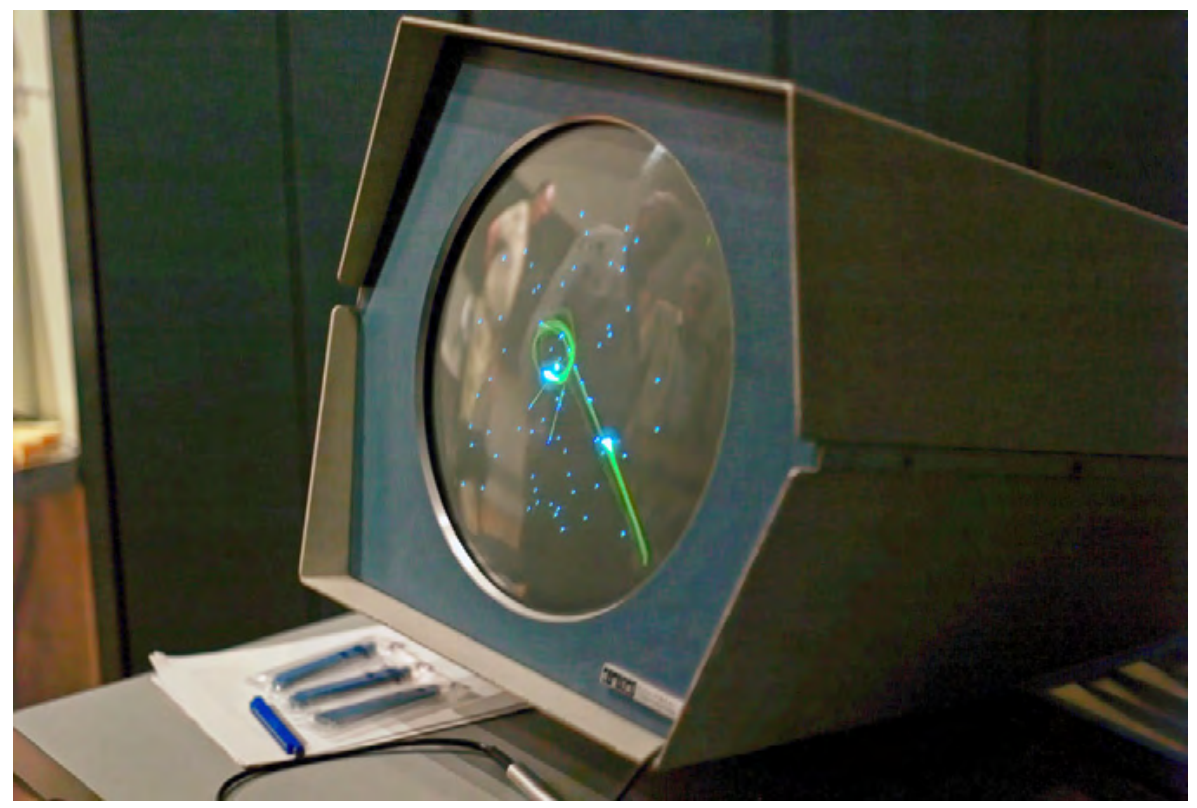

Rysunek 2. Spacewar! (1961)

Weźmy Spacewar! z 1961 roku. Już w samym tytule kryje się obietnica niesamowitej przygody - wojny w kosmosie, między dwoma statkami. Podobnie jak w Tennis for Two o żadnym liczniku punktów zwycięstwa nie ma mowy. Dlatego, mimo że dość szybko zaczynają powstawać gry, w których, tak jak w niewirtualnym pierwowzorze, rywalizacja odgrywa kluczowe znaczenie (jak w szachach, warcabach czy nawet później w tenisie za sprawą Ponga), równie ważne stają się opowieści i wprowadzenie gracza w historię, wytworzenie w jego umyśle narracji, którą on sam będzie dalej budował. 


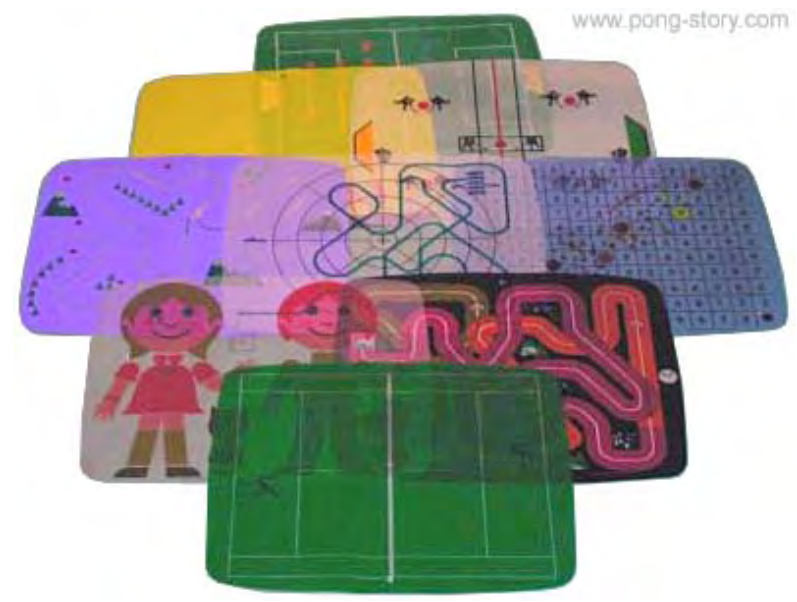

Rysunek 3. Nakładki na telewizor do Magnavox Odyssey

Magnavox Odyssey (1972) Ralpha Baera to w zasadzie pierwsza konsola do gier przeznaczona dla licznego grona odbiorców, bo podłączana do telewizora. Biorąc pod uwagę rosnącą popularność telewizji w USA, a także telewizyjne początki Baera ${ }^{9}$ - jak wieść niesie, ponoć o konsoli myślał już w początku lat 50. XX wieku - jest to w zasadzie ścisły początek gier komputerowych znanych obecnie. Do Magnavox Odyssey dodawane są interesujące nakładki na telewizor, w różnych rozmiarach i kolorach. Oto do gry w strzelanie (imitacja prawdziwej strzelby, podłączana do konsoli) dołączona zostaje nakładka $\mathrm{w}$ formie nawiedzonego domu (w okienkach pojawią się duchy), z którymi walczy gracz. Do gry w tenisa, protoplasty klasycznego już Ponga Nolana Bushnella, mamy na przykład nakładkę na telewizor imitującą kort tenisowy. Jeśli spojrzeć na zasadność dodawania takich elementów z perspektywy narracyjnej, widać wyraźnie, że chodzi nie tylko o ,zwiększenie realizmu”, ale także wzbudzanie u odbiorców konkretnych,

\footnotetext{
${ }^{9}$ Ibidem, s. 14.
} 
narracyjnych ciągot do dopowiadania sobie tego wszystkiego, co nie mogło być pokazane w grze ze względu na ograniczenia technologiczne.

Choć w tej początkowej fazie rozwoju gier zwycięstwo odgrywa nadal ważną rolę (zliczanie punktów, możliwość pojedynkowania się z innym graczem), równolegle, bardzo powoli, na znaczeniu zyskuje także aspekt narracyjny. Twórcy coraz więcej pracy wkładają w odtworzenie jakiejś sytuacji na ekranie, stworzenie ułudy rzeczywistości, danie graczowi poczucia, że bierze udział w jakiejś wyjątkowej historii. Ma to znaczenie tym większe, że owe ,growe” pierwociny są najczęściej niezbyt atrakcyjne wizualnie, nie porywają odbiorców. Ot, zlepek kilku kwadratów i prostokątów na ekranie. Oczywiście wciąż w tym początkowym okresie rozwoju znajdziemy mnóstwo przykładów rywalizacyjnych, a więc typowych dla gier znanych z ich bardziej tradycyjnych form - mamy więc zwycięzcę i przegranego, a w wypadku porażki jedyne, co możemy zrobić, to uruchomić grę od nowa. Niemniej jednak stopniowo, acz systematycznie gry rozwiną się na tyle, że odejdą od tego klasycznego modelu i staną się czymś pomiędzy grą, a bardziej wyrafinowaną twórczością, gdzie oprócz zwycięstwa czy porażki liczy się także fabuła, opowieść, którą „,sprzedają” nam twórcy.

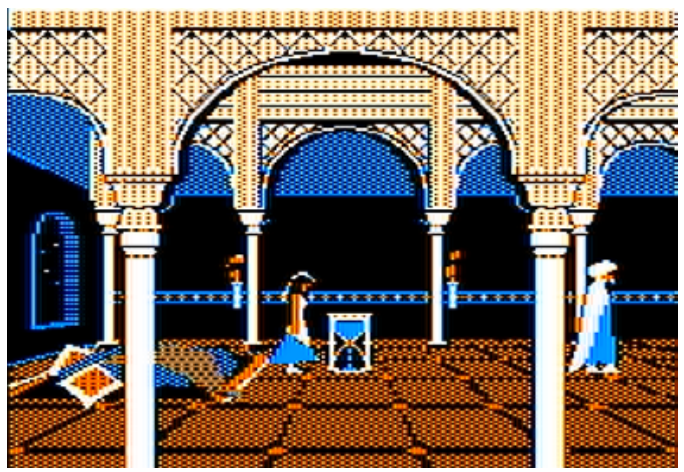

Rysunek 4. Prince of Persia (1989) 
By jeszcze lepiej to wyjaśnić, spójrzmy na jedną z ważniejszych gier w historii - Prince of Persia. Powstała w 1989 roku i fabularną kanwę stanowiła w niej opowieść o uratowaniu księżniczki więzionej przez okrutnego sułtana. Gracz, wcielając się w rolę tytułowego księcia Persji, miał za zadanie w ciągu 60 minut realnie upływającego czasu pokonać 13 poziomów, na których oprócz pułapek na gracza czekali też nasłani przez sułtana przeciwnicy. Śmierć oznaczała rozpoczęcie gry od nowa i wyzerowanie licznika, ale na szczęście w grze zaimplementowano kody, umożliwiające przeskakiwanie do wybranych plansz po ich wcześniejszym ukończeniu. Choć gra trwała maksymalnie 60 minut, czas który musiał poświęcić gracz, ze względu na trudności wynikające z samej rozgrywki, był znacznie dłuższy. W 60 minut można było pokonać grę, ale pod warunkiem, że już się ją znało i gracz wiedział, co robić na kolejnych planszach, by jak najszybciej je przejść i dotrzeć do komnaty z księżniczką. W takim projekcie gry kluczowy wydaje się aspekt rywalizacyjny, typowy choćby dla gier planszowych - mamy jasne zasady zwycięstwa i jasne zasady porażki, a do owej mechaniki rozgrywki dorzuconą szczątkową „fabułkę”.

W taki sposób historia ta została opowiedziana ponad 20 lat temu. Gra doczekała się jednak uwspółcześnionej wersji, z podtytułem Classic, w której w zasadzie wszystkie wyzwania pierwowzoru i trudności wynikające $\mathrm{z}$ ograniczenia czasowego zostały usunięte, by grę dało się ukończyć w sposób wybrany przez gracza.

Esencja rozgrywki jest jednak wciąż taka sama (akcję obserwujemy z boku i mimo że grafika jest trójwymiarowa, gracz i tak obserwuje akcję w ograniczającym rzucie).

Zgodnie z trendami obowiązującymi obecnie w branży gier wideo, produkuje się gry, które jedynie tytułem nawiązują do pierwowzorów sprzed lat. Dzięki temu gra może poszczycić się pewną historią związaną z obecnością marki już przez kilka(naście) lat na rynku, a równocześnie w kwestiach samej rozgrywki czy fabuły z pierwowzorami sprzed lat ma niewiele wspólnego. 


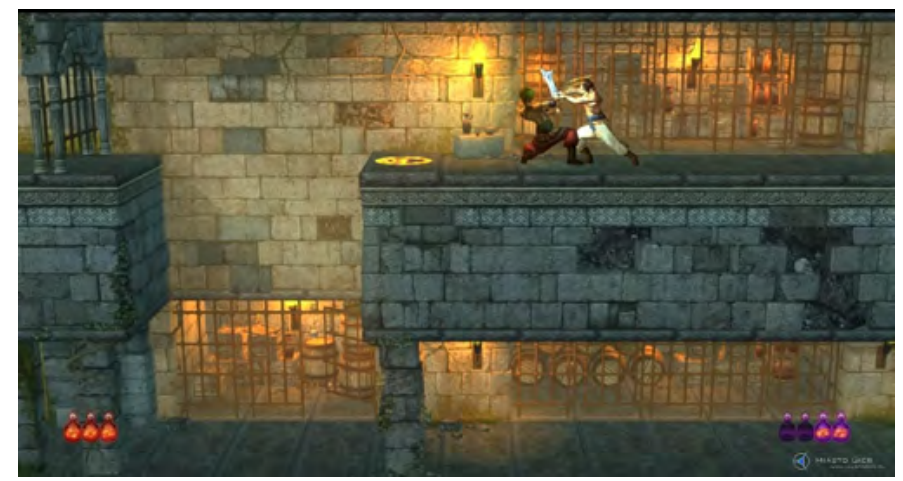

Rysunek 5. Prince of Persia Classic (2007)

I właśnie taką wersję Prince of Persia należy postawić na przeciwległym biegunie tworzenia gier, by pokazać, jak zmieniły się dziś czasy i jak dalece współczesne gry zamiast aspektu rywalizacyjnego, typowo ,growego”, kładą nacisk na opowieść, a więc narrację.

Przyjrzyjmy się zatem wydanej w 2008 roku nowej odsłonie Prince of Persia, by pokazać, że zjawisko, o którym piszę, a więc dominacyjna rola narracji, która stopniowo przez lata rozwoju gier nabierała coraz większego znaczenia, nie jest jedynie wymysłem autora.

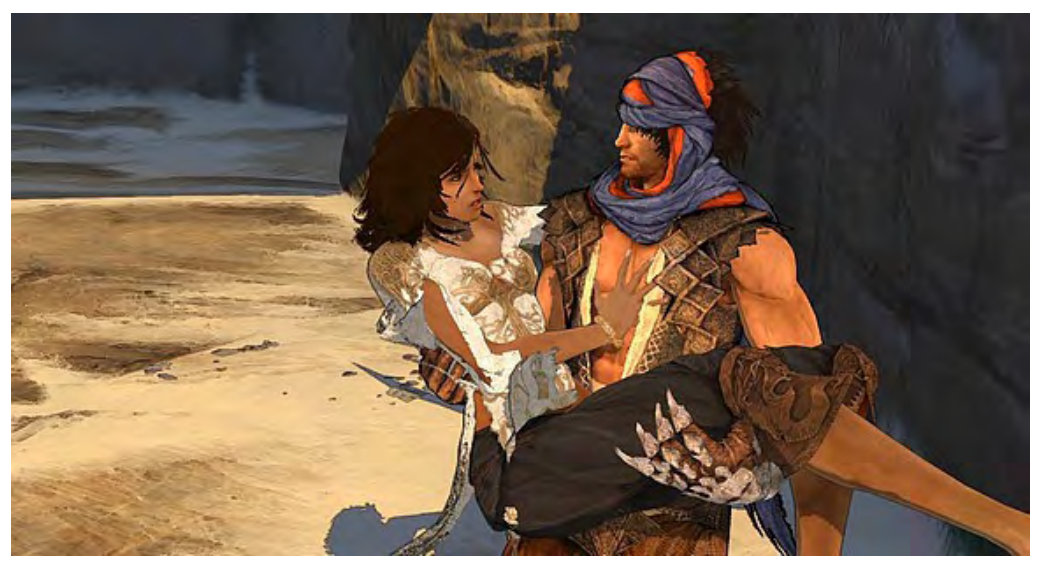

Rysunek 6. Prince of Persia (2008) 
W Prince of Persia (2008) nie można nie tylko zginąć, lecz także nie można w ogóle przegrać. Gra w doskonały sposób pokazuje, jak dziś projektuje się gry wideo. Za każdym razem, gdy nasz bohater spadnie w przepaść, towarzysząca mu bohaterka, sterowana przez komputer, ratuje go w wymownej animacji - widzimy jak chwyta naszego księcia za rękę. Podobnie rzecz ma się w walce na miecze z przeciwnikami - tu także, nawet jeśli poziom życia naszego bohatera spadnie, wówczas automatycznie gra nie pozwala nam zginąć (możemy w zasadzie przestać sterować postacią i nic się nie stanie). Centralnym punktem staje się bowiem przygodowa opowieść, a nie sprawdzenie się gracza w typowo ,growych” elementach. Jest to oczywiście przypadek skrajny, ale w gruncie rzeczy potwierdzający regułę-dziś opowieść czy też przyświecająca twórcom chęć wzbudzenia narracji u gracza, ma charakter powszechny i stanowi kwintesencję grania. Nie chodzi już tylko o znaczniki zwycięstwa, które wciąż dominują na przykład w świecie tradycyjnych gier planszowych. Chodzi raczej o zabranie odbiorcy na porywającą opowieść, w której doświadczy czegoś, co być może zna z telewizji, kina, literatury. Przegrana lub wygrana w zasadzie schodzi na plan dalszy, bowiem jedynym sposobem, w jaki możemy przegrać, grając we współczesną wersję Prince of Persia, jest wyłączenie gry. Poszczególne elementy spotykane na drodze w trakcie zabawy nie stanowią najmniejszego wyzwania, grę ukończy w zasadzie każdy. A jeśli każdy, to gdzie rywalizacja, pole do wyłonienia najlepszego?

Ta chęć opowiadania historii, w której to właśnie gracz wchodzi w rolę narratora, thumaczy stopniowe zjawisko dodawania do kolejnych gier coraz to bardziej rozbudowanych fabuł. Komputerowy tenis przeszedł drogę od Tennis for Two, w którym mamy tylko pojedynczy mecz, do czasów Top Spin 4 (2011), gdzie tworzymy własnego zawodnika, bierzemy udział w turniejach, a w toku rozgrywki nasz zawodnik rozwija się i sterowanie nim staje się stopniowo łatwiejsze. 
Dlatego w „nieistniejącym sporze” między ludologami a narratywistami ${ }^{10}$ wypada mi stwierdzić, że mimo wszystko gry są opowieściami, a to gracz (co pokażę dalej) pełni w nich rolę narratora.

\section{Gra wideo jako idealne symulakrum}

Teoria symulakrów i symulacji Jeana Baudrillarda ${ }^{11}$ powstała ponad trzydzieści lat temu. I choć wówczas gry wideo były jedynie lichymi pierwocinami tego, co dziś gości na ekranach komputerów czy zaawansowanych technologicznie konsol do gier, to właśnie one są w moim odczuciu jedną z najlepszych współczesnych ilustracji zjawisk, o których pisze francuski filozof.

Symulacja to udawanie, że ma się coś, czego się nie ma. Jednak według Baudrillarda chodzi tu o taki rodzaj symulacji, w którym przejmuje ona cechy zjawiska naśladowanego. Jak chory, który nabywa objawów choroby przez siebie symulowanej. Różnica między „prawdziwym” a „fałszywym” lub „rzeczywistością” a „wyobrażeniem” staje się w zasadzie niemożliwa do uchwycenia. W ten sposób wyobrażenie zaczyna wytwarzać rzeczywistość. Symulakrum, a więc obraz w całości będący symulacją, może pozorować rzeczywistość lub też wytwarzać zupełnie nową, własną rzeczywistość, którą Baudrillard nazywa hiperrzeczywistością. Jest ona bardziej rzeczywista od samej rzeczywistości.

Według francuskiego filozofa, mamy dziś do czynienia właśnie z precesją symulakrów, a więc zalewem obrazów zapośredniczonych, nie odsyłających już do rzeczywistości, a jedynie przetwarzających inne obrazy. Można nawet zaryzykować stwierdzenie, że rzeczywistość nie istnieje. Nie chodzi

${ }^{10}$ G. Frasca, Ludolodzy też kochają opowiadania, [w:] Światy z pikseli. Antologia studiów nad grami komputerowymi, wybór i koncepcja M. Filiciak, Warszawa 2010, s. 78 .

${ }^{11}$ J. Baudrillard, Symulakry i Symulacja, Warszawa 2005, rozdział Precesja symulakrów. 
tu bynajmniej o fakt, że żyjemy w próżni. Precesja symulakrów uniemożliwia odbiorcy nie tyle samo dotarcie do rzeczywistości, ile raczej poprawne jej zrekonstruowanie, odróżnienie jej od wytworzonej przez symulakrum hiperrzeczywistości.

W teorię Baudrillarda doskonale wpisują się współczesne gry wideo. Wejście w świat gry jest o wiele silniejszym doświadczeniem niż oglądanie filmu. Uczestnicząc w rozgrywce, gracz musi całą uwagę skupić na wydarzeniach w grze, w przeciwnym razie granie będzie niemożliwe. To zaangażowanie jest tak silne, że ciężko je zrozumieć komuś, kto nigdy w gry nie grał. Obserwując rozgrywkę z boku, znad ramienia osoby grającej, widzimy jedynie mniej lub bardziej odrażający brutalnością czy też zupełnie nużący spektakl, taki nieudolnie zrobiony film. Dopiero jeśli sami zagramy, dostrzeżemy tę kolosalną różnicę między filmem a grą.

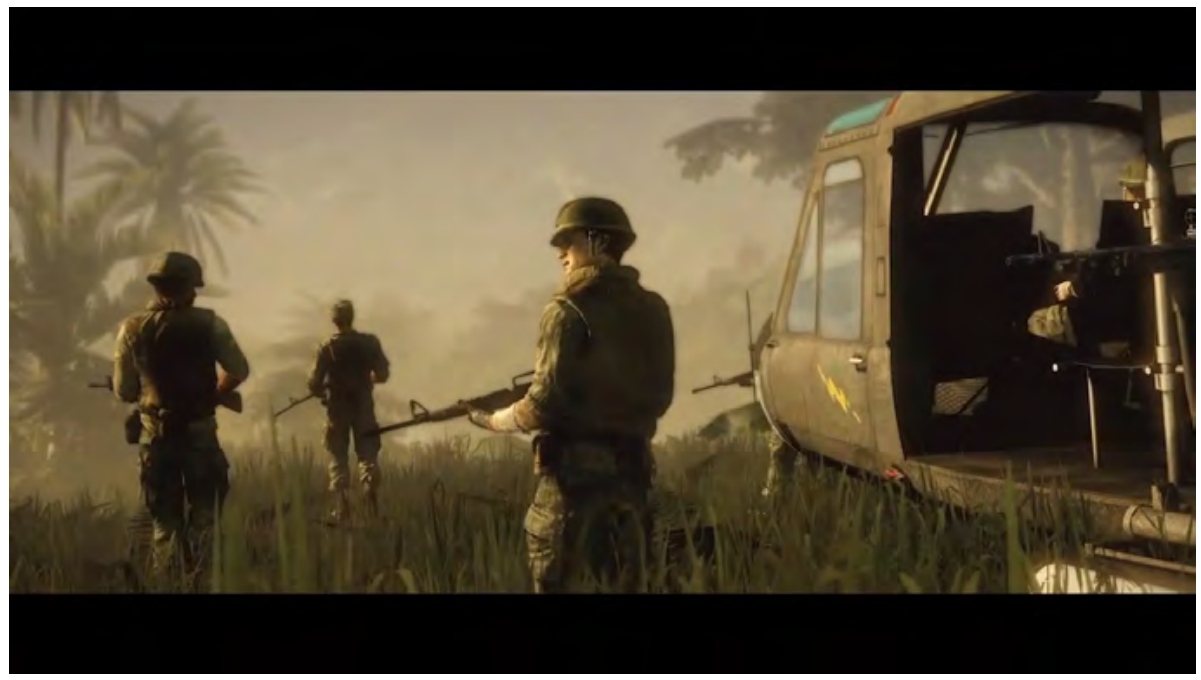

Rysunek 7. Battlefield Bad Company 2 Vietnam - kadr ze zwiastuna gry, nawiązujący do filmów wojennych o konflikcie w Wietnamie 
W grze wojennej z gatunku FPS ${ }^{12}$ pod tytułem Battlefield: Bad Company 2 - Vietnam, twórcy na warsztat wzięli wojnę w Wietnamie. Jednak jako że gra jest przeznaczona tylko do rozgrywki sieciowej (a więc walka toczy się zawsze z innymi graczami za pośrednictwem Internetu), nie mamy tu fabuły w tradycyjnym sensie znanym z filmów czy literatury. Zamiast tego możemy wziąć udział w różnych operacjach znanych z wojny w Wietnamie, sprowadzonych do potyczek na niewielkich wirtualnych mapach. Na pierwszy rzut oka wszystko się zgadza, mamy sprzęt wojskowy z tego okresu - zarówno broń, jak i pojazdy - także krajobrazy są właściwe. Jednak gra dość szybko odsyła nas do specyficznego ujęcia tego konfliktu, znanego z filmu Francisa Forda Coppoli - Czasu apokalipsy. Jest w nim scena ataku kawalerii powietrznej na wioskę wietnamską, która rozgrywa się przy dźwiękach Cwału Walkirii Wagnera płynących z głośników zamontowanych na helikopterach. Otóż ten motyw - a więc głośniki umieszczone na pojazdach - znajduje swoje odbicie w grze. Dochodzi w niej do podobnej sytuacji, co w filmie. Kiedy mamy przebitkę na wioskę tuż przed nalotem i nie widząc jeszcze helikopterów, słyszymy gdzieś w oddali narastającą stopniowo muzykę Wagnera. Zanurzając się w rozgrywce, odkrywamy coś zupełnie niezwykłego, wynikającego z zestawienia tych elementów - muzyki i świszczących dookoła gracza kul, tumanów kurzu wzniecanych przez szaleńcze eksplozje. Powstaje jakiś trudny do opisania taniec śmierci, odsyłający jednak nie do rzeczywistej wojny (to gra, niekiedy, by zabić żołnierza przeciwnika, trzeba w niego wpakować cały magazynek), ale do filmu Coppoli. I jeśli przyjmiemy za Baudrillardem, że już sam film jest sumulakrum, odsyłającym do rozmachu charakterystycznego dla prowadzonych przez amerykanów wojen, to tym bardziej gra wideo, odnosząca się już tylko do filmu, takim

${ }^{12}$ First Person Shooter - ang. strzelanina $\mathrm{z}$ widokiem z pierwszej osoby. Jest to swoisty podgatunek gier FPP (First Person Perspective - gra z widokiem z pierwszej osoby). 
symulakrum być musi, bowiem wpisuje się w tę samą narrację o wojnie w Wietnamie, co amerykańskie filmy (muzyka, świszczące dookoła kule, ujęcia będące w zasadzie kliszami filmowych).

Podobnie sprawa ma się z grami wojennymi, których akcja rozgrywa się w okresie II wojny światowej. Zamiast odsyłać nas do prawdziwej wojny, tego jak ona faktycznie wyglądała ${ }^{13}$, być może przez posiłkowanie się relacjami prawdziwych świadków tych wydarzeń, gry wideo będą nas odsyłać do wyobrażeń na temat konkretnych działań wojennych lub innych wypadków historycznych, jakie ukształtowała w naszej świadomości kultura masowa, a więc kino i ewentualnie literatura.

\section{Performatywny charakter gier wideo}

O ile film ma chyba największy estetyczny wpływ na gry wideo przez wspomniane zapośredniczenie, o tyle nie można zapomnieć, że grom wideo jest także bardzo blisko do teatru (a być może to tylko złudne wrażenie teatralnego widza i gracza jednocześnie) ${ }^{14}$. W zasadzie, patrząc na gry wideo z perspektywy Estetyki performatywności Eriki Fisher-Lichte, nie sposób oprzeć się wrażeniu, że zwrot performatywny, jaki dokonał się w teatrze w latach $60 .{ }^{15}$, jest w gruncie rzeczy obecny od samego początku w grach wideo.

Podobnie jak performans lub przedstawienie teatralne, gry wideo odbywają się tu i teraz. Bez gracza nie ma gry. Jest on składową wymaganą

${ }^{13}$ Wstrzymajmy się na chwilę z pytaniem, czy w ogóle takie dojście do prawdy jest możliwe.

${ }^{14} \mathrm{~W}$ bardzo ciekawej dyskusji na łamach 99. numeru Didaskaliów publicyści związani ze światem gier (Olaf Szewczyk i Paweł Schreiber) nie doszli do zadowalającego porozumienia $\mathrm{z}$ twórcami teatralnymi (Pawłem Passinim, Janem Klatą, Wiktorem Rubinem). Owa dyskusja przypominała raczej okopanie się na z góry upatrzonych pozycjach. Nie zmienia to jednak faktu, że w perspektywie tego, o czym pisze Erika Fisher-Lichte na temat performansu, odnajduję bardzo wiele wspólnych obszarów między grami i teatrem.

${ }^{15}$ E. Fisher-Lichte, Estetyka performatywności, Kraków 2008, s. 26. 
dla przedstawienia. Podobieństw jest jednak więcej: wyjątkowość spektaklu, który za każdym razem może odbyć się o innej porze, który zawsze może różnić się przypadkowymi zdarzeniami, ale też w ogólnych zarysach, jest całkowicie zaprojektowanym wydarzeniem, w którym twórcy starają się $\mathrm{w}$ gruncie rzeczy przewidzieć reakcje widzów i w jakiś sposób na nie przygotować. Podobnie jest z grami wideo. Od nas zależy, o jakiej porze zasiądziemy do gry; wchodząc w grę, wchodzimy w tę samą przestrzeń, co widz teatralny, przy czym gracz wchodzi w nią wirtualnie, natomiast widz teatralny fizycznie. I mimo tego wejścia wirtualnego, a więc bez udziału wszystkich zmysłów, gra wideo potrafi znacznie mocniej i niemal od razu wessać odbiorcę w swoją hiperrzeczywistość. Tymczasem do dziś teatr boryka się z mieszczańskim wyobrażeniem spektaklu (wyciemniona widownia, cisza podczas przedstawienia, brak jakiejkolwiek reakcji poza sformalizowanymi oklaskami $)^{16}$. Weźmy na przykład „Personę. Marilyn” Krystiana Lupy. W spektaklu, w którymś momencie padają słowa, że bohaterów ktoś obserwuje. Gest aktorów wskazuje, że ów tajemniczy podglądacz znajduje się daleko za widownią. Reakcja widzów - znikoma. Nikt, poza piszącym te słowa, nie odwraca się, by sprawdzić, czy aktorzy nie kłamią. To w gruncie rzeczy niewielkie doświadczenie dowodzi, że mieszczański charakter odbioru spektaklu jest wciąż tak silny w widzach, że nawet próby przełamania go takimi - wydawałoby się mało inwazyjnymi zabiegami - muszą spalić na panewce.

Tymczasem gry wideo wciągają odbiorców znacznie bardziej. Z pasywnego widza, skrywającego się wyraźnie za granicą ociemnionej widowni, przekształcają gracza w pełnoprawnego uczestnika

${ }^{16}$ Piszę to na podstawie moich ostatnich doświadczeń teatralnych, po obejrzeniu spektakli Teatru Dramatycznego: Don Kichot Macieja Podstawnego, Persona. Marilyn Krystiana Lupy, Kto zabit Alonę Iwanowna Michała Kmiecika. 
wydarzeń, który ma kolosalny (choć w dalszym ciągu zaprojektowany wcześniej) wpływ na przedstawiane wydarzenia.

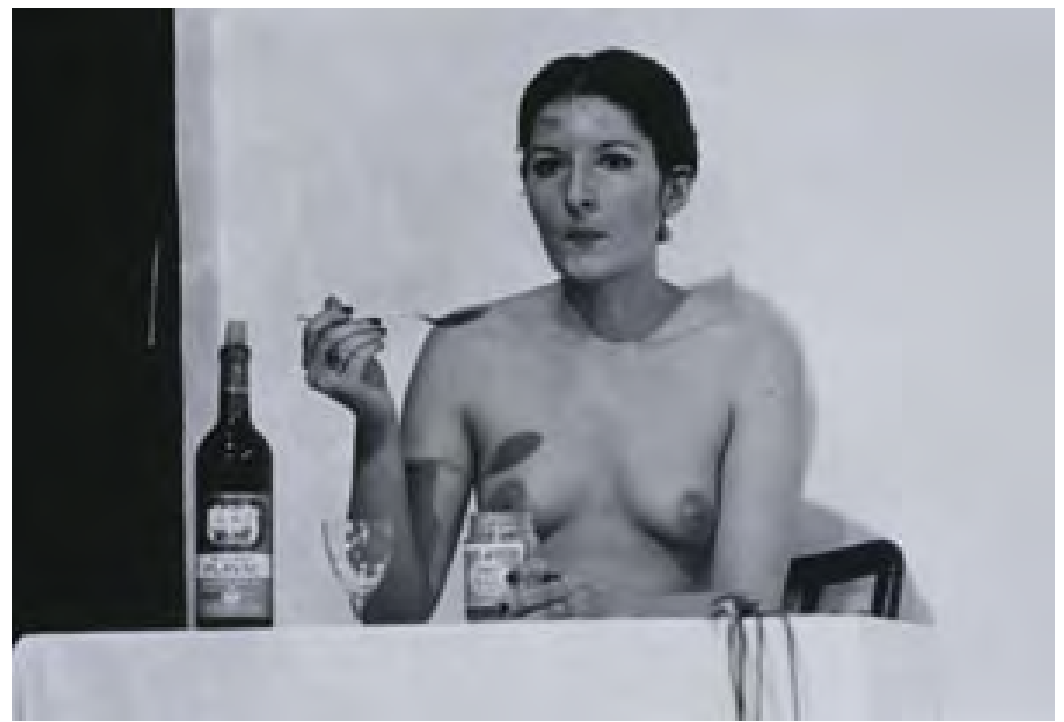

Rysunek 8. Marina Abramović podczas perfomransu Lips of Thomas

Warto jeszcze wspomnieć o performansie Mariny Abramović z 24 października $1975 \mathrm{roku}^{17}$. Widzowie musieli uczestniczyć w przedstawieniu, które niekoniecznie mogło być dla nich przeżyciem komfortowym. Mogli wyjść, oglądać i ewentualnie przerwać performans (co też uczynili). Być może mogli też coś pokrzykiwać lub w inny sposób zamanifestować swoje niezadowolenie/zadowolenie. Mieli jednak - tak sądzę - skończony zasób reakcji, które wcześniej musiała przewidzieć autorka performansu: oglądanie do końca, przerwanie lub po prostu wyjście w trakcie. Wszystkie zachowania widzów da się zapewne podciągnąc pod każdą z tych trzech wymienionych nadrzędnych grup zachowań, a czy przerwanie przedstawienia nastąpi w wyniku wezwania policji, rzucania pomidorami czy jeszcze czegoś innego, jest

${ }^{17}$ E. Fisher-Lichte, op. cit., s. 11. 
z perspektywy twórcy sprawą drugorzędną. Musi przygotować sobie plan działania i ewentualnej reakcji na te trzy grupy zachowań widzów. Tak samo postępują twórcy gier wideo, programując je, tyle że interaktywny spektakl toczy się w przestrzeni wirtualnej, wytworzonej gdzieś w umyśle gracza głównego narratora opowieści.

\section{Half-Life}

Half-Life (1998) wprowadził szereg zmian do samej narracji w grach FPP, a także w zasadzie zdefiniował, jak powinna wyglądać nowoczesna gra z tego gatunku. Rozwiązania zastosowane w Half-Life są obecne (w różnorakiej formie) we wszystkich współcześnie tworzonych grach.

Arystotelesowski podział narracji na początek, środek i koniec ${ }^{18}$ (wstęp, rozwinięcie i zakończenie) dopiero od Half-life'a zaczyna być jasno i precyzyjnie stosowany w grach FPP (ale też w innych gatunkach). Oczywiście w takich grach jak Wolfenstein 3D, Doom czy Quake również funkcjonuje, jednak jest tam mało finezyjnie wpleciony w strukturę gry. Bo przecież możemy uznać, że wstępem jest pierwsza plansza w Doomie (czyli ta najłatwiejsza) następnie rozwinięcie to wszystkie środkowe etapy prowadzące do finalnej walki, a owa finalna walka to samo zakończenie. Całość ujęta w ramy wyznaczone przez tandetne kino akcji, w którym samotny śmiałek musi stawić czoła hordom wrogów, a na końcu wyjść z tego zwycięsko i tym samym ocalić ludzkość.

${ }^{18}$ Arystoteles, Poetyka, [w:] tegoż, Retoryka. Poetyka, thum. H. Podbielski, Warszawa 1988, s. 323-334. 


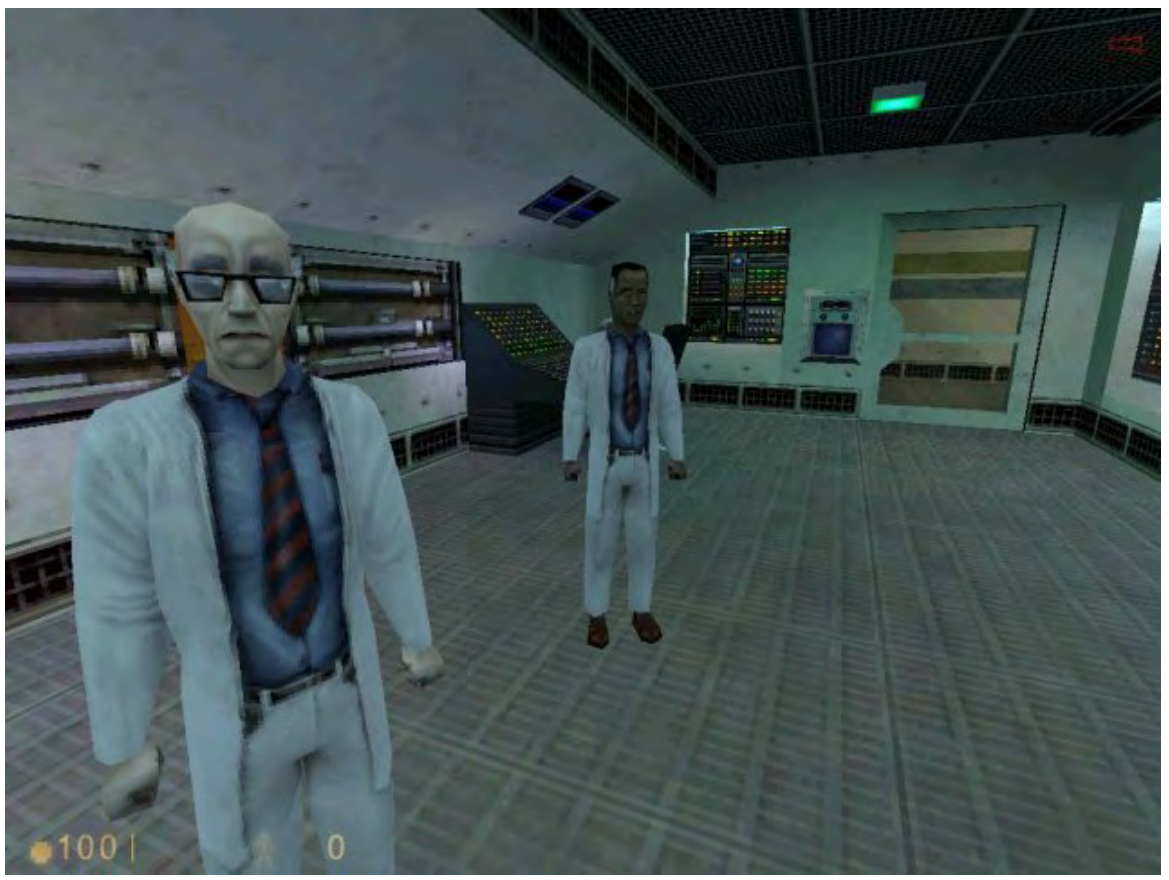

Rysunek 9. Half-Life

Tymczasem twórcy Half-Life zaproponowali coś zupełnie innego. Nie tylko bardzo wyraźnie i zarazem finezyjnie podzielili całą opowieść na poszczególne etapy (wstęp, rozwinięcie, zakończenie), lecz także zastosowali kilka bardzo interesujących chwytów w samym sposobie opowiadania, wykorzystując jakże oczywisty fakt, że w centrum wydarzeń znajduje się gracz i niemal w fizyczny sposób eksploruje świat.

Wprowadzenie do gry, a więc podróż specjalnym wagonikiem kolejki transportowej do najbardziej strzeżonego laboratorium rządowej agencji Black Mesa, w 1998 roku robiło niesamowite wrażenie. Po prostu czegoś takiego gracze jeszcze nie widzieli. Po pierwsze, wagonik cały czas się poruszał po torach (gracz nie mógł go zatrzymać, ale mógł w środku swobodnie się poruszać), a za jego oknami podziwialiśmy kolejne sekcje rządowego kompleksu badawczego, w którym prowadzi się najbardziej zaawansowane 
badania. Tu ktoś próbował dostać się do zamkniętych drzwi, tu jakiś duży, transportowy robot przenosił $\mathrm{z}$ miejsca na miejsce wielkie ładunki itd. Słowem, siedząc w wagoniku, gracz obserwował świat, który de facto żył własnym życiem. W ten sposób twórcy wciągali gracza znacznie bardziej w opowiadaną historię. Half-Life pokazywał świat, który żyje swoim życiem, obok właściwej rozgrywki. Twórcy odwoływali się tu do innej narracji, a mianowicie tej o wielkich agencjach rządowych, które w ściśle tajnych kryjówkach prowadzą zaawansowane technologicznie badania, w tym wypadku nad alternatywną rzeczywistością. Tego rodzaju narracja znana jest doskonale z kina, chociażby z Gier wojennych z 1983 w reż. Johna Badhama.

\section{Hiperrealistyczna wojna}

Wyprodukowany w 1998 roku film Steven Spielberga pt. Szeregowiec Ryan być może nie był wielkim artystycznym osiągnięciem, nawet mimo otrzymania przez reżysera statuetki Oscara. Niemniej siła oddziaływania tego dzieła na współczesną kulturę popularną jest niepodważalna. Duża w tym zasługa znakomitych zdjęć Janusza Kamińskiego (także nagrodzonego Oscarem), a zwłaszcza znakomicie przedstawionej sceny lądowania na plaży Omaha. I to właśnie ta scena odcisnęła ogromne piętno na grach z gatunku FPP, rozwijając pomysły zaprezentowane w Half-Life. Nie bez znaczenia jest też fakt, że seria Medal of Honor została zapoczątkowana przez studio Dreamworks Interactive, którego współzałożycielem był sam Steven Spielberg. Ale mimo że pierwsza gra z tej serii powstała w 1999 roku, a więc rok po sukcesie Szeregowca Ryana, została wydana na przestarzałą już wtedy technologicznie konsolę PlayStation ${ }^{19}$ i nie zawierała w sobie żadnych innowacyjnych pomysłów. Dopiero wydana trzy lata później gra pt. Medal of Honor: Allied Assault okazała się drugim ważnym krokiem w rozwoju gier FPP po słynnym Half-Life. Być może dlatego, że powstała na PC.

\footnotetext{
${ }^{19}$ Chodzi o PlayStation 1, a więc pierwszą generację konsoli Sony.
} 
Gra czerpała z palety środków zaprezentowanych w Half-Life. Po pierwsze, zamiast w superbohatera, wcielaliśmy się w zwykłego szeregowca Mike'a Powella. Bohater, mimo że uczestniczy w szeregu misji, nigdy nie wypowiada ani słowa, a równocześnie nieustannie żołnierze towarzyszący mu w trakcie walki wydają nam polecenia, co i w którym momencie robić. $\mathrm{Z}$ perspektywy naszego bohatera obserwujemy więc w zasadzie wszystkie wydarzenia na froncie wraz ze zmieniającymi się na naszych oczach warunkami zwycięstwa (nowe cele pojawiające się dynamicznie w grze). Każda z misji ma swój wstęp (w którym w zasadzie obserwujemy spektakl odgrywany przez program, dokładnie na takiej samej zasadzie, jak otwierająca grę jazda kolejką w Half-Life), rozwinięcie, a więc zasadniczą część rozgrywki, i zakończenie. Twórcy wprawdzie nie zrezygnowali z przerywników filmowych, jednak mimo wszystko nie odgrywają one aż takiej roli, stanowią jedynie pewne uzupełnienie narracji prowadzonej przez gracza (by było jasne, dlaczego akcja przerzuca się z Włoch na plaże Normandii).

Medal of Honor: Allied Assault wprowadza jednak element dotąd niespotykany na tę skalę. W grze w jednej misji gracz uczestniczy w lądowaniu na plaży Omaha ${ }^{20}$. Scena nie tylko odwołuje się bezpośrednio do filmu Szeregowiec Ryan ${ }^{21}$. Pamiętam, że kiedy grałem w tę grę po raz pierwszy, ponad dziesięć lat temu, miałem niemal ciarki na plecach. Perspektywa zagrania w film (który sam w sobie nie przypadł mi do gustu) była na tyle pociągająca, że elektryzowała moją wyobraźnię. Uwidacznia się tu zarazem największa różnica między grami a filmami. Nawet najlepiej zrealizowane kino akcji, z setką najlepszych efektów specjalnych, musi zmierzyć się z pasywną rolą odbiorcy, który „tylko” ogląda. Gra wideo pozwala tymczasem na ,zagranie

${ }^{20}$ Misję można obejrzeć w serwisie YouTube, np. pod adresem: http://youtu.be/ tCR-w8PE1ZA.

${ }^{21}$ A w zasadzie do otwierającej film sceny tegoż lądowania. 
w film", a więc pokierowanie losami szeregowca, który w huku strzałów i wśród świszczących dookoła pocisków uczestniczy w desancie wojsk alianckich w czasie II wojny światowej. Scena w grze została zrealizowana tak jak w filmie. Jeden z żołnierzy coś wykrzykuje, zagrzewając nas do walki, inny się modli, powoli w oddali wyłania się plaża, zaczynają swój koncert działa przeciwdesantowe itd. A gracz jest w samym centrum tego kotła; nie możemy wprawdzie poruszać się po łodzi transportowej, ale możemy swobodnie ruszać głową, obserwując to, co dzieje się dookoła. W końcu łódź dobija do brzegu i wchodzimy na pole walki już z pełną kontrolą postaci. Biegniemy przed siebie, kucamy za zasiekami ustawionymi na plaży, widzimy, jak obok ktoś pada, ktoś biegnie dalej, wszędzie świst pocisków i terkot

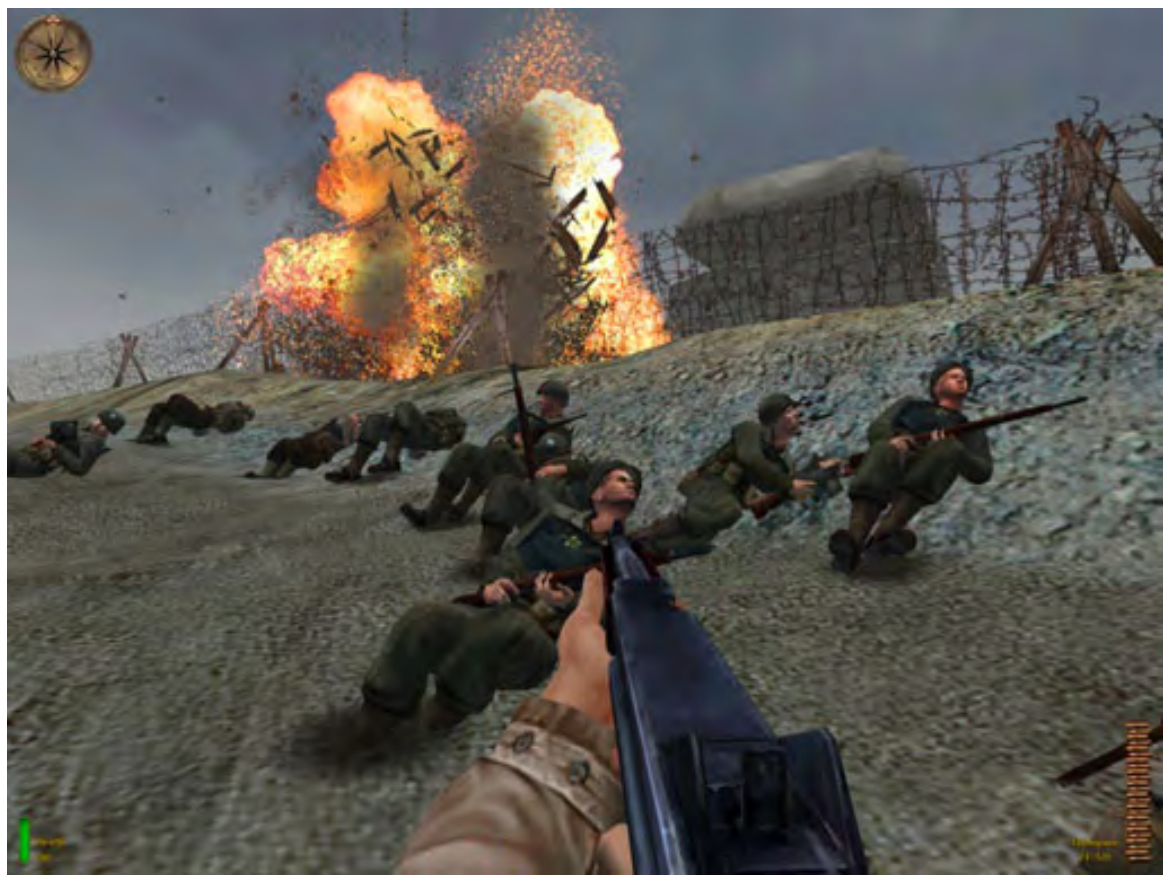

Rysunek 10. Medal of Honor: Allied Assault - lądowanie na plaży Omaha 
karabinów maszynowych, w końcu dobiegniemy pod wydmę, aby podobnie jak w filmie użyć bazooki. Narracyjna rola gracza w gruncie rzeczy polega na podjęciu decyzji, co zobaczymy lub nie. Którędy pobiegniemy, na co zwrócimy uwagę, a co przegapimy. Jednak wejście w świat gry jest nieporównywalnie silniejszym przeżyciem, niż oglądanie filmu czy nawet granie w gry z początku lat 90 . I to nie tylko dlatego, że gry stały się znacznie bardziej zaawansowane technicznie, ale dlatego że owo techniczne zaawansowanie umożliwiło korzystanie ze stale powiększającej się palety środków narracyjnych.

Niemniej kluczowe wydaje się tutaj owo Baudrillardowskie zapośredniczenie, wykreowanie na ekranie hiperrzeczywistości, która wpisuje się w dominującą narrację o II wojnie światowej, ukształtowaną przez popkulturę. Gra odsyła nas bowiem do filmu, a nie do prawdziwej wojny. Mimo dużej dbałości o historyczny detal, raczej można być pewnym, że to, w jaki sposób pokazał nam lądowanie na plaży Omaha Spielberg, niekoniecznie musi być zgodne z prawdą, a raczej na pewno jest „upiększonym” obrazem tegoż lądowania. Gra komputerowa tworzy więc swoją własną hiperrzeczywistość, realniejszą od samej rzeczywistości, w której bród, zapach śmierci i krew oraz wszystko to, co kojarzy się z tą masakrą, zostaje wzięte przez autorów w duży cudzysłów.

W Call of Duty: Modern Warfare 2 (2009) twórcy zaserwowali nam jedną z najbardziej kontrowersyjnych misji w historii gier wideo - No Russian ${ }^{22}$. Jako zakamuflowany agent, infiltrujący terrorystów, gracz uczestniczy w masakrze na lotnisku. Pominę kwestie kontrowersyjności, które jeszcze przed premierą skutecznie podniosły temperaturę i tak już gorącej gry. Misja wygląda następująco: rozpoczynamy w windzie, gdzie tylko słuchamy (jeszcze

${ }^{22}$ Wspomnianą scenę można obejrzeć w serwisie YouTube pod adresem: http:// youtu.be/8NMnnMRWJ-0. 


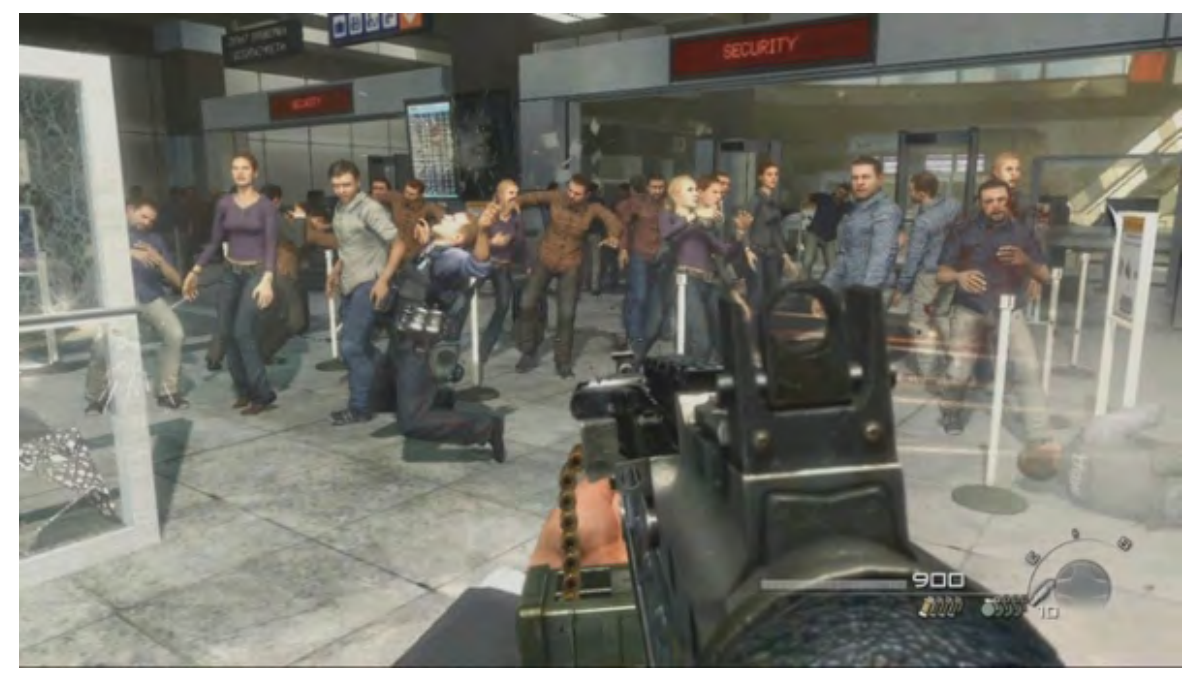

Rysunek 11. Call of Duty: Modern Warfare 2 - misja No Russian

w ciemności) naszego zwierzchnika - terrorysty. Następnie rozświetlenie, winda się zatrzymuje, otwierają się drzwi. Towarzyszy nam czterech terrorystów, wszyscy ubrani w kamizelki, z potężnymi karabinami. I teraz wchodzą w przestrzeń lotniska w Moskwie. Widzimy dziesiątki pasażerów, z głośników zaczyna dobiegać nerwowa muzyka. Nasi towarzysze specjalnie się nie ociągają, unoszą karabiny i zaczynają na oczach gracza (który w tym momencie może już swobodnie się poruszać i również strzelać) „pruć” do wszystkiego, co się rusza. Ludzie padają, ktoś się czołga ranny, zostawiając za sobą szkarłatny ślad krwi itd. Gracz jest świadkiem tej dantejskiej sceny, rzezi niewiniątek - co może zrobić? Może tylko przyłączyć się do oprawców, nie może ich zastrzelić (choć przecież byłoby to możliwe, ale twórcy nie dają nam takiej opcji). Możemy ewentualnie iść i nie strzelać, biernie się przyglądając. Scena słusznie budzi wiele kontrowersji. Mamy możliwość wyłączyć grę lub w opcjach zaznaczyć, że tej akurat misji nie chcemy rozgrywać. Zasób danych nam możliwości jest tu skończony i bardzo mocno ograniczony. Paradoksalnie, scena ta pokazuje pewną ułudę nieliniowości gier komputerowych. Zawsze będziemy bowiem poruszali się po ścieżkach 
uprzednio zaplanowanych przez twórców, z mniejszym lub większym marginesem swobody. Jednak margines ten jest zawsze ściśle określony przez twórców. Paradoksalnie też, choć imersja jest tutaj przeogromna (gracz się krzywi, wyłącza komputer, lub - o zgrozo - zaczyna sam strzelać do niewinnych ofiar), sytuacja przypomina performans Mariny Abramović, który również miał skończoną, ściśle określoną i zaplanowaną liczbę rozwiązań, przewidzianych przecież przez autorkę. Opisywana scena być może jest tandetnie kontrowersyjna, ale równocześnie pokazuje, jak silne emocje w graczu może wzbudzić gra, jak silnie może go zaangażować, doprowadzając nawet do przerwania rozgrywki (lub spektaklu w przypadku performansu).

\section{Podsumowanie}

Współczesne gry komputerowe trudno rozpatrywać wyłącznie w kategoriach czystej rozgrywki. Na przestrzeni lat daje się zaobserwować gigantyczny postęp nie tylko technologiczny, lecz także idący za nim rozwój środków narracyjnych, pozwalający wciągać gracza w opowieść na różne sposoby. Czy będzie to zapośredniczenie odwołujące się do dzieł kultury masowej, czy może wręcz przeciwnie - oddanie graczowi ogromnej palety możliwości, które powodują, że rozgrywka w zasadzie może toczyć się bez końca. Jedno jest jednak pewne, patrząc na historię gier komputerowych, nie sposób oprzeć się wrażeniu, że pochód w stronę samej narracji, zwiększania jej roli i co za tym idzie powolna jej dominacja, sprawia, że gry wideo należy rozpatrywać coraz częściej w kategoriach opowieści, na które sami mamy wpływ.

Kwestia wciągnięcia odbiorcy w strukturę narracyjną dzieła zależy wyłącznie od autorów. Podobnie jak w teatrze, który może posiłkować się performansem. Warto jednak pamiętać, że zasób reakcji widowni, nawet dla twórców sztuki performatywnej, jest w gruncie rzeczy skończony. Widzowie moga przerwać spektakl, wytrzymać do końca lub wyjść w trakcie. Natomiast sposób przerwania jest już sprawą drugorzędną. Tak samo jak fakt, że publiczność, choćby i najbardziej 
awangardowa, będzie zawsze poruszać się w ramach ograniczanych kulturą osobistą czy społecznie akceptowalnymi normami. Dopiero przełamanie tych norm przez twórców może wyzwolić widzów. Owo przełamanie jednak jest niczym innym niż świadomym wyborem twórcy, który de facto uśmierca całą ideę nieprzewidywalności wpisaną $\mathrm{w}$ performans.

\section{Spis ilustracji}

Rysunek 1 Tennis for Two Williama Higinbothama na oscyloskopie5 Rysunek 2 Spacewar! (1961)6

Rysunek 3 Nakładki na telewizor do Magnavox Odyssey7

Rysunek 4 Prince of Persia (1989)8

Rysunek 5 Prince of Persia Classic (2007)9

Rysunek 6 Prince of Persia (2008)10

Rysunek 7 Micki i Mallory Knox jako urodzeni mordercy i zarazem idole massmediów15

Rysunek 8 Battlefield Bad Company 2 Vietnam - kadr ze zwiastuna gry, nawiązujący do filmów wojennych o konflikcie w Wietnamie16 Rysunek 9 Marina Abramović podczas perfomransu Lips of Thomas19 Rysunek 10 Wolfenstein 3D21

Rysunek 11 Half-Life 23

Rysunek 12 Medal of Honor: Allied Assault - lądowanie na plaży Omaha28

Rysunek 13 Call of Duty: Modern Warfare 2 - misja No Russian29

Rysunek 14 Left4Dead (2008)31

Rysunek 15 Elder Scrolls V: Skyrim (2011)32 


\section{Videogame Player as Narrator - Based on FPP Games}

Even though film is having the biggest esthetical impact on videogames, player's participation during the gameplay suggests rather a theatrical - performative trope. It shouldn't be however the reason to question narrative aspects of videogames. In this article I signal that mainstream videogames are drifting away from competition and moving closer to narration of interesting stories, in which a player is participating and also becomes a narrator. I describe this occurrence using Erika Ficher-Lichte's performative esthetics and Jean Baudrillard's simulation theory.

Keywords: narration, videogames, performance, simulacrum, simulation. 


\section{Wydawnictwo Uniwersytetu Kardynała Stefana Wyszyńskiego}

Polecamy ostatnio wydane publikacje
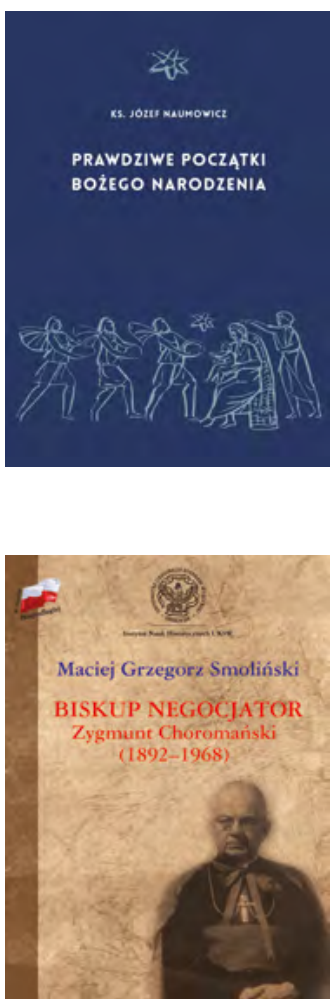

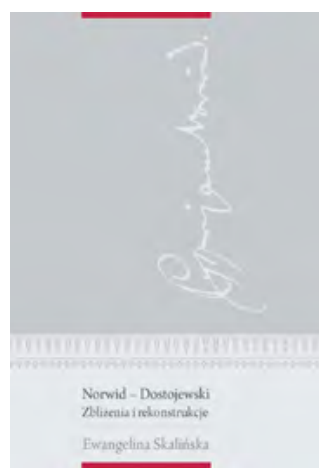

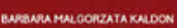

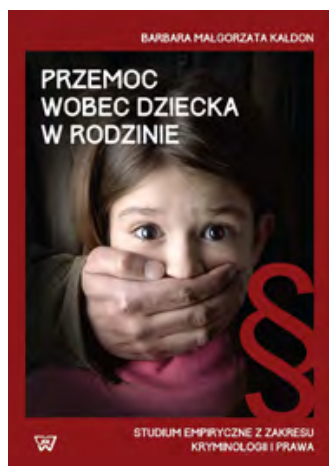

$W^{\text {ydawnictwo UKSW pu- }}$ blikuje książki naukowe i popularnonaukowe: monografie, rozprawy doktorskie i habilitacyjne, tomiki poezji, materiały pokonferencyjne, podręczniki i prace zbiorowe, o tematyce obejmującej wszystkie dziedziny, w których Uniwersytet Kardynał Stefana Wyszyńskiego prowadzi badania naukowe oraz kształcenie.

Wydawnictwo UKSW ul. Dewajtis 5, Warszawa tel. 225618838 